\title{
USE OF CORRELATION ANALYSIS TO EXAMINE RELATIONSHIP BETWEEN TAX BURDEN AND BUSINESS ENVIRONMENT IN SELECTED EU COUNTRIES
}

The aim of the article is to examine the relationship between tax burden and business environment in Slovakia, Czech Republic and Germany. The examination is carried out using correlation analysis to identify the level of dependence between selected indicators of tax burden and number of business entities in selected countries. The article contains also analysis and comparison of found facts.

Keywords: Tax burden, corporate income tax, tax rate, CIT-to-GDP-ratio, tax-to-GDP-ratio, direct taxes-to-GDP-ratio, implicit tax rate on corporate income, business entities, correlation analysis, correlation coefficient.

\section{Introduction}

In general, tax burden is considered an important factor in decision making about the business activity of enterprises in particular country. Taxes affect many areas of the business sector, particularly economic behaviour and subsequent financial decisions of business units. Among the applicable taxes, direct taxes have more impact on cost-effectiveness or profits of enterprises as indirect ones. In the paper the relationship between tax burden and business environment in Slovakia, Czech Republic and Germany is examined using correlation analysis. These three countries were chosen to compare Slovakia with the country that has similar history, tradition and economic and tax system and is of comparable level of development (Czech Republic) and with more developed country with different history, tradition and economic and tax system (Germany). Thanks to the differences found out through the research we can compare the effectiveness of different tax systems in relationship with business environment.

\section{Data and methodology}

For the purpose of examining the relationship between tax burden and business environment we selected specific indicators representing tax burden on the macroeconomic level, namely nominal tax rate on corporate income (CIT rate), tax-to-GDPratio, implicit tax rate (ITR) on corporate income, share of direct taxes to GDP (direct taxes-to-GDP-ratio) and share of corporate income taxes to GDP (CIT-to-GDP-ratio). Tax rate is used to determine the actual level of business taxes from the tax base. Tax-to-GDP-ratio (namely the aggregate tax-to-GDP-ratio) is commonly used for international comparison of tax burden and is defined as a share of all taxes, levies, duties and non-tax payments to the GDP of a country. Implicit tax rate on corporate income is defined as a share of taxes on income or profits of businesses on their total income. The share of direct taxes to GDP and the share of corporate income tax to GDP is an expression of the tax burden of these taxes. These indicators were selected because of their expected impact on the business environment, as well as their availability on international statistics, in particular on Eurostat, the statistical office of the European Union. The business environment is represented by number of business entities, particularly entities that are potential taxpayers of corporate income tax. In this analysis we abstract away from other influences affecting the business environment, and the attention is focused only on the impact of tax burden.

Number of business entities - legal persons, was considered the variable $y$ and the individual indicators of tax burden were identified as $x_{1}$ (tax rate on corporate income), $x_{2}$ (tax-to-GDPratio), $x_{3}$ (implicit tax rate), $x_{4}$ (share of direct taxes to GDP) and $x_{5}$ (share of corporate income taxes to GDP). Gradually, we investigated linear dependence between the variable $y$ and $x_{1}, x_{2}, x_{3}, x_{4}$ and $x_{5}$ using the method of correlation analysis, and therefore the correlation coefficients reflecting the degree of the dependence, were calculated [1].

The input data are values of selected indicators for the years 2003 to 2010 in Slovakia, Czech Republic and Germany.

\section{Relationship between indicators of tax burden and business environment in Slovakia}

Table 1 contains the input data for Slovakia used in correlation analysis.

\footnotetext{
* Magdalena Brezaniova

Department of Communications, Faculty of Operation and Economics of Transport and Communications, University of Zilina, Slovakia

E-mail: magdalenabrez@gmail.com
} 
Values of selected indicators of business environment and tax burden in Slovakia for the years 2003 to 2010

Table 1

\begin{tabular}{|l|c|c|c|c|c|c|c|c|}
\hline Indicator/year & 2003 & 2004 & 2005 & 2006 & 2007 & 2008 & 2009 & 2010 \\
\hline Number of business entities $(y)$ & 101412 & 114285 & 126777 & 139240 & 149772 & 169960 & 179352 & 197089 \\
\hline CIT rate [\%] $\left(x_{1}\right)$ & 25 & 19 & 19 & 19 & 19 & 19 & 19 & 19 \\
\hline Tax-to-GDP-ratio [\%] $\left(x_{2}\right)$ & 33 & 31.7 & 31.5 & 29.4 & 29.5 & 29.4 & 29.1 & 28.3 \\
\hline ITR on corporate income [\%] $\left(x_{3}\right)$ & 34.8 & 22.6 & 23.3 & 20.3 & 19.8 & 21.7 & 22.5 & 19.2 \\
\hline Direct taxes-to-GDP-ratio [\%] $\left(x_{4}\right)$ & 7.1 & 6.1 & 6.0 & 6.1 & 6.2 & 6.5 & 5.5 & 5.4 \\
\hline CIT-to-GDP-ratio [\%] $\left(x_{5}\right)$ & 2.8 & 2.6 & 2.7 & 2.9 & 3.0 & 3.1 & 2.5 & 2.5 \\
\hline
\end{tabular}

(Source: Own elaboration by using data from Slovak Statistical Office and Eurostat) [2], [3]

Number of business entities in Slovakia during the examined period of time is shown in Fig. 1.

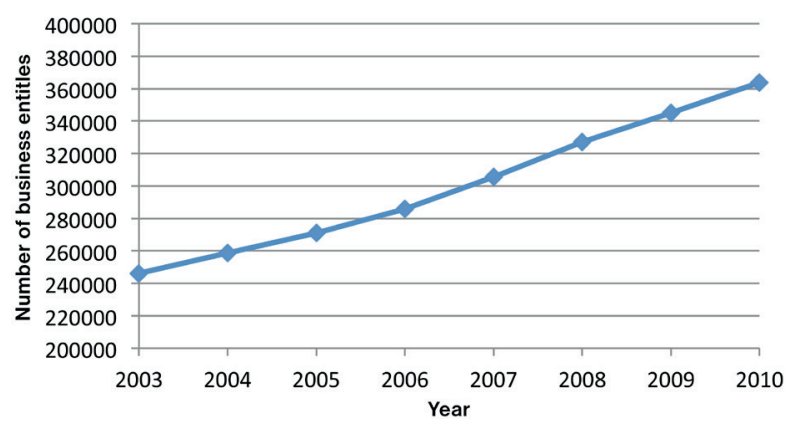

Fig. 1 Number of business entities in Slovakia between 2003 and 2010. (Source: own elaboration by using data from Slovak Statistical Office) [2]

In Fig. 2 we can see time characteristic of selected indicators of tax burden for Slovakia in $2003-2010$.
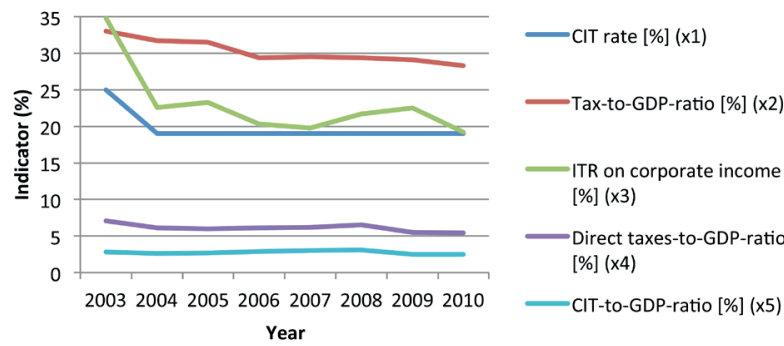

Fig. 2 Time characteristic of selected indicators of tax burden in Slovakia in 2003 - 2010

(Source: Own elaboration by using data from Eurostat) [3]
The values of correlation coefficients of selected indicators for Slovakia are shown in Table 2.

Correlation coefficients for the examination of dependence between selected indicators in Slovakia

Table 2

\begin{tabular}{|c|c|}
\hline Indicators & Correlation Coefficients \\
\hline $\mathrm{y}, \mathrm{x}_{1}$ & -0.558 \\
\hline $\mathrm{y}, \mathrm{x}_{2}$ & -0.925 \\
\hline $\mathrm{y}, \mathrm{x}_{3}$ & -0.653 \\
\hline $\mathrm{y}, \mathrm{x}_{4}$ & -0.709 \\
\hline $\mathrm{y}, \mathrm{x}_{5}$ & -0.179 \\
\hline
\end{tabular}

where $y$ is the number of business entities (legal persons), $x_{1}$ is tax rate on corporate income tax, $x_{2}$ is Tax-to-GDP-ratio, $x_{3}$ is Implicit tax rate on corporate income, $x_{4}$ is Direct taxes-to-GDP ratio, $x_{5}$ is CIT-to-GDP ratio (Source: author's calculation)

The values of correlation coefficients in Table 2 show that in Slovakia the strongest dependence is between number of business entities and the overall tax burden, measured by tax-to-GDP-ratio. The correlation coefficient in this case has the value of -0.925 , and thus it is a negative linear correlation. Between the other examined indicators and number of business entities is only medium or low dependence. Therefore, we can conclude that in Slovakia among the selected indicators the most important for business activity is tax-to-GDP-ratio and the reduction of its level is accompanied by an increase in number of business entities.

As seen from the data in Table 1 and Figs. 1 and 2, during the monitored period the number of business entities in Slovakia was increasing, with the largest increase in 2008 (20 188 companies more than in 2007). Conversely, the lowest increase in number of business entities was recorded in 2009 (by 9 392), which should be considered a result of the financial crisis. Tax-to-GDPratio was decreasing during the period, except for 2007, when a slight increase by $0.10 \%$ was recorded. Its most significant decrease was in 2006 (by $-2.10 \%$ ). This can be considered the effect of the tax reform adopted in previous two years, in which 
besides the introduction of the flat tax rate for income tax and VAT, the method of income taxation in Slovakia had changed (including increased basic personal allowance to $19.2 \mathrm{x}$ minimum subsistence level), the preferential treatment of taxation of business activities of legal persons applying the linear tax rate compared to natural persons had been abolished, the terms of quantifying the income tax base, which was obtained from the activities of the same nature (in particular, income of business) had been unified, and the application of deductible expenses from taxable income and the application of business losses from previous years had been introduced. In 2006, the reduced VAT rate of $10 \%$ was introduced for selected commodities. Other examined indicators of tax burden were developing variously and their values had not significant influence on number of business entities. Worthy of notice is corporate income tax rate, which declined markedly in 2004 (by 6\%) after the above mentioned tax reform related with the introduction of flat tax rate of $19 \%$, which was also reflected in considerable decrease of implicit tax rate on corporate income (by $12.19 \%$ ) [4].

\section{Relationship between indicators of tax burden and business environment in Czech Republic}

Table 3 shows the input data for the Czech Republic used in correlation analysis.

Number of business entities in the Czech Republic during the examined period of time can be seen in Fig. 3.

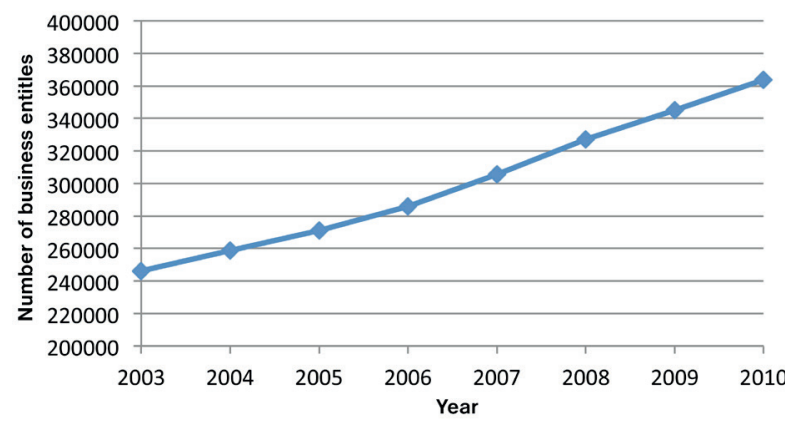

Fig. 3 Number of business entities in Czech Republic between 2003 and 2010 (Source: own elaboration by using data from Czech Statistical Office) [5]
In Fig. 4 there is time characteristic of selected indicators of tax burden for the Czech Republic in 2003 - 2010.

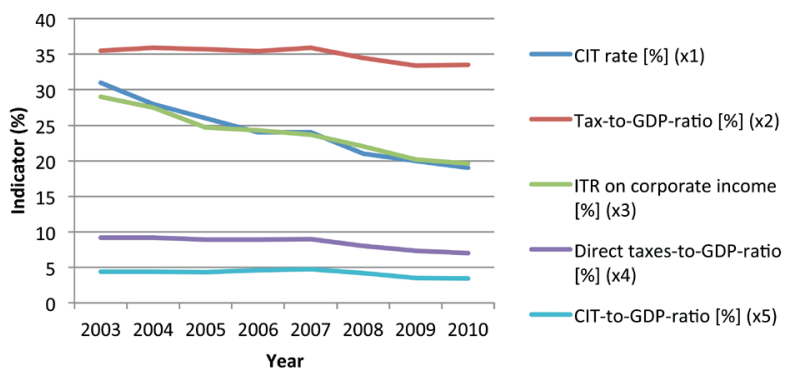

Fig. 4 Time characteristic of selected indicators of tax burden in Czech Republic in 2003 - 2010

(Source: own elaboration by using data from Eurostat) [3]

The values of correlation coefficients of selected indicators for Czech Republic are shown in Table 4.

Correlation coefficients for the examination of dependence between selected indicators in Czech Republic Table 4

\begin{tabular}{|c|c|}
\hline Indicators & Correlation Coefficients \\
\hline $\mathrm{y}, \mathrm{x}_{1}$ & -0.969 \\
\hline $\mathrm{y}, \mathrm{x}_{2}$ & -0.865 \\
\hline $\mathrm{y}, \mathrm{x}_{3}$ & -0.972 \\
\hline $\mathrm{y}, \mathrm{x}_{4}$ & -0.934 \\
\hline $\mathrm{y}, \mathrm{x}_{5}$ & -0.752 \\
\hline
\end{tabular}

where $y$ is the number of business entities (legal persons), $x_{1}$ is tax rate on corporate income tax, $x_{2}$ is Tax-to-GDP-ratio, $x_{3}$ is Implicit tax rate on corporate income, $x_{4}$ is Direct taxes-to-GDP ratio, $x_{5}$ is CIT-to-GDP ratio (Source: author's calculation)

In Czech Republic four indicators of tax burden have strong correlation with number of business entities (Table 4). The strongest dependence is between number of business entities and implicit tax rate on corporate income. In this case the value of the correlation coefficient is -0.972 . Due to its minus sign the decrease of implicit tax rate on corporate income reflects an

Values of selected indicators of business environment and tax burden in the Czech Republic for the years 2003 to 2010

Table 3

\begin{tabular}{|l|c|c|c|c|c|c|c|c|}
\hline Indicator/year & 2003 & 2004 & 2005 & 2006 & 2007 & 2008 & 2009 & 2010 \\
\hline Number of business entities $(y)$ & 246181 & 258674 & 271242 & 285943 & 305707 & 327173 & 345156 & 363801 \\
CIT rate [\%] $\left(x_{l}\right)$ & 31 & 28 & 26 & 24 & 24 & 21 & 20 \\
Tax-to-GDP-ratio [\%] $\left(x_{2}\right)$ & 35.5 & 35.9 & 35.7 & 35.4 & 35.9 & 34.5 & 33.4 & 33.5 \\
ITR on corporate income [\%] $\left(x_{3}\right)$ & 29.0 & 27.5 & 24.7 & 24.3 & 23.7 & 22.0 & 20.2 \\
Direct taxes-to-GDP-ratio [\%] $\left(x_{4}\right)$ & 9.2 & 9.2 & 8.9 & 8.9 & 9.0 & 8.0 & 7.3 & 7.0 \\
CIT-to-GDP-ratio [\%] $\left(x_{5}\right)$ & 4.4 & 4.4 & 4.3 & 4.6 & 4.7 & 4.2 & 3.5 \\
\hline
\end{tabular}

(Source: Own elaboration by using data from Czech Statistical Office and Eurostat) [3], [5] 
increase in number of business entities. Similar situation is in the case of corporate income tax rate (the correlation coefficient is equal to -0.969), and the share of direct taxes to GDP (-0.934). Slightly smaller, but still strong dependence is between number of business entities and overall tax-to-GDP-ratio. Between number of business entities and share of income tax to GDP is only medium correlation, so we could conclude that the effect of this variable to number of business entities - legal persons in the country is the least.

Throughout the monitored period tax rate on corporate income, as well as implicit tax rate on corporate income, decreased or remained unchanged, while the downward trend of these two parameters was among monitored indicators the most notable (Table 3, Figs. 3 and 4). The course of values of the other studied indicators was variable and there were only slight changes in values. Number of business entities was increasing every year. The largest increase in number of business entities was in 2008 (by 21466 ), at the same year as there was the greatest reduction in corporate income tax rate (by $3 \%$, as well as in 2004) and the second largest decrease in implicit tax rate on corporate income (by $1.75 \%$, the largest decrease of the indicator was in 2005, by $2.50 \%)$. These decreases in values of the indicators were due to implementation of tax reforms in the Czech tax system in 2004 and 2008.

\section{Relationship between indicators of tax burden and business environment in Germany}

Table 5 contains the input data for Germany used in correlation analysis. In the case of Germany, we examined the dependence using four indicators of the tax burden, whereas data on implicit tax rate on corporate income for the examined period was not available. Number of business entities (in this case all enterprises regardless of their legal status) is for the years 20062010, data for previous years was not available.
Number of business entities in Germany during the examined period of time is shown in Fig. 5.

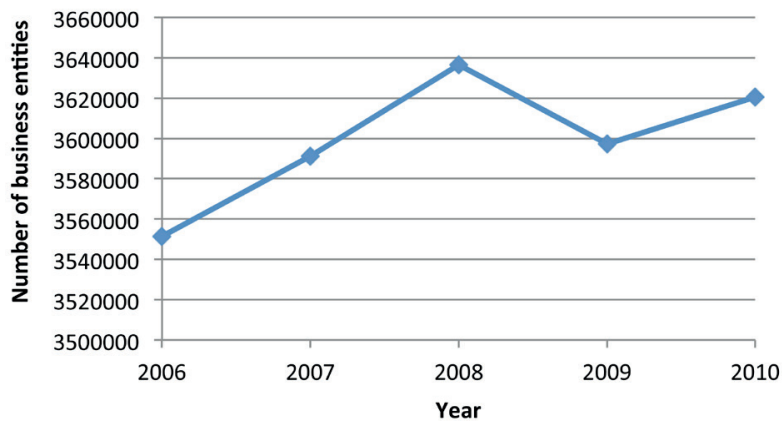

Fig. 5 Number of business entities in Germany between 2006 and 2010 (Source: own elaboration by using data from German Statistical Office) [6]

In Fig. 6 time characteristic of selected indicators of tax burden for Germany in $2003-2010$ is shown.

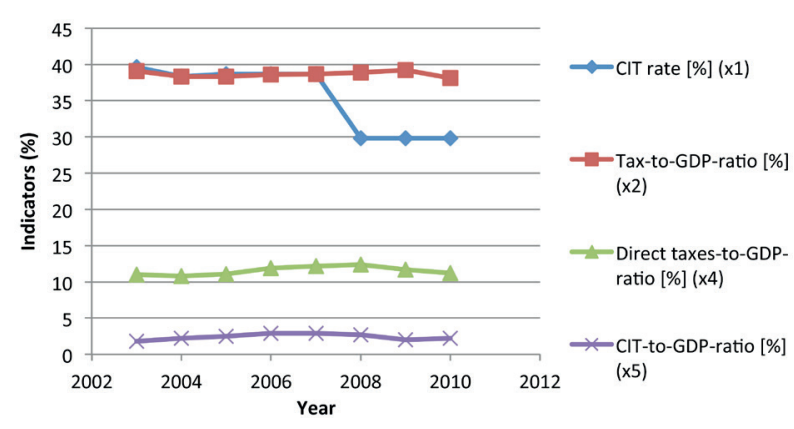

Fig. 6 Time characteristic of selected indicators of tax burden in Germany in 2003 - 2010

(Source: own elaboration by using data from Eurostat) [3]

Values of selected indicators of business environment and tax burden in Germany for the years 2003 to 2010

Table 5

\begin{tabular}{|l|c|c|c|c|c|c|c|c|}
\hline Indicator/year & 2003 & 2004 & 2005 & 2006 & 2007 & 2008 & 2009 & 2010 \\
\hline $\begin{array}{l}\text { Number of business } \\
\text { entities }(y)^{*}\end{array}$ & - & - & - & 3551240 & 3591265 & 3636495 & 3597248 & 3620576 \\
\hline CIT rate [\%] $\left(x_{1}\right)^{* *}$ & 39.6 & 38.3 & 38.7 & 38.7 & 38.7 & 29.8 & 29.8 & 29.8 \\
\hline $\begin{array}{l}\text { Tax-to-GDP-ratio [\%] } \\
\left(x_{2}\right)\end{array}$ & 39.1 & 38.3 & 38.3 & 38.6 & 38.7 & 38.9 & 39.2 & 38.1 \\
\hline $\begin{array}{l}\text { ITR on corporate } \\
\text { income [\%] }\left(\mathrm{x}_{3}\right)\end{array}$ & 24.0 & 25.4 & 24.3 & 30.0 & 27.7 & 25.9 & 14.7 & 21.6 \\
\hline $\begin{array}{l}\text { Direct taxes-to-GDP- } \\
\text { ratio [\%] }\left(x_{4}\right)\end{array}$ & 11.0 & 10.8 & 11.1 & 11.9 & 12.2 & 12.4 & 11.7 & 11.2 \\
\hline $\begin{array}{l}\text { CIT-to-GDP-ratio } \\
{[\%]\left(x_{5}\right)}\end{array}$ & 1.8 & 2.2 & 2.5 & 2.9 & 2.9 & 2.7 & 2.0 & 2.2 \\
\hline
\end{tabular}

* number of business entities includes all companies in Germany, data on the number of enterprises - legal persons separately was not available

** it is total tax rate, i.e. statutory tax rate + solidarity surcharge + local trade tax

(Source: Own elaboration by using data from German Statistical Office and Eurostat) [3], [6] 
The values of correlation coefficients of selected indicators for Germany are shown in Table 6.

Correlation coefficients for the examination of dependence between selected indicators in Germany

\begin{tabular}{|c|c|}
\hline Indicators & Correlation Coefficients \\
\hline $\mathrm{y}, \mathrm{x}_{1}$ & -0.791 \\
\hline $\mathrm{y}, \mathrm{x}_{2}$ & -0.029 \\
\hline $\mathrm{y}, \mathrm{x}_{3}$ & - \\
\hline $\mathrm{y}, \mathrm{x}_{4}$ & 0.028 \\
\hline $\mathrm{y}, \mathrm{x}_{5}$ & -0.377 \\
\hline
\end{tabular}

where $y$ is the number of business entities (legal persons), $x_{1}$ is tax rate on corporate income tax, $x_{2}$ is Tax-to-GDP-ratio, $x_{3}$ is Implicit tax rate on corporate income,

$x_{4}$ is Direct taxes-to-GDP ratio, $x_{5}$ is CIT-to-GDP ratio (Source: author's calculation)

As for Germany, we can see that the most of the selected indicators of tax burden has no significant impact on the evolution of number of business entities, since the most values of correlation coefficients indicate only low dependence between monitored indicators. An exception is the tax rate on corporate income, which has nearly strong dependence with number of business entities (correlation coefficient $=-0.791$, Table 6 ). This indirect dependence was reflected in the most significant increase in the number of business entities in 2008 (about 45,230 more than in 2007), when was the most significant reduction in the total tax rate on corporate income $(+8.9 \%)$ to $29.8 \%$ of previous $38.7 \%$ (due to a reduction in the statutory tax rate to $15 \%$ ) - Fig. 6. It is worth noting also marked reduction of the number of business entities in 2009 - there were 39,247 less companies registered than in 2008 - Fig. 5. It is therefore clear that business activity in Germany was negatively influenced by the financial crisis that erupted in autumn 2008. In the development of the values of the other studied variables of tax burden, there were no significant fluctuations [7].

As we can see from the used data, the values of selected indicators of tax burden are the highest in Germany. On the other hand also the number of business entities in this country is really high. Based on these findings, we can conclude that the business environment in Germany is affected more by factors different from tax burden. Germany is a developed country with a developed infrastructure, high levels of health care and education system, with a good legal system and advanced use of modern technologies, so business entities are willing to do business in this country in spite of higher tax burden.

\section{Conclusion}

Comparing the three chosen countries we can find differences in relationship between tax burden and business environment. From the values of correlation coefficients follow that most significantly influenced by tax burden is business environment in Czech Republic, where four indicators of tax burden have strong correlation with number of business entities (corporate income tax rate, overall tax-to-GDP-ratio, implicit tax rate on corporate income, share of direct taxes to GDP). In Slovakia we found strong dependence of one indicator of tax burden to business environment - the overall tax burden, measured by tax-to-GDPratio. In Germany the results showed that no of the selected indicators of tax burden has significant impact on the evolution of number of business entities.

Based on the findings from the analysis we can conclude that in creating favourable conditions for business activity in Slovakia, attention should be focused primarily on reducing the overall tax burden, so various measures in tax policy to reduce the tax burden should be implemented. In the Czech Republic business entities have responded favourably primarily on decrease of corporate income tax rates, as well as implicit tax rate on corporate income, so it is appropriate to focus on other items affecting the tax base, too. One possibility to make business environment more attractive is to support small and medium enterprises with preferential taxation.

\section{Acknowledgements}

The contribution is processed as a part of the research projects VEGA $1 / 1321 / 12$ Research of new trends in management in the era of globalization and KEGA 070ZU-4/2011 Management and network entrepreneurship in knowledge economics and VEGA 1/0895/13 Research on strategic business management as promoting competitiveness in a dynamic business environment.

\section{References}

[1] CHAJDIAK, J.: Statistical exercises and their solutions in Excel (in Slovak), Bratislava, STATIS, 2005. ISBN 80-85659-39-5

[2] Statistical Office of the Slovak Republic, [online] Available on Internet: http://www.statistics.sk/pls/elisw/casovy_Rad.procDlg

[3] Taxation Trends in the European Union. Data for the EU Member States, Iceland and Norway. Eurostat Statistical Books. European Union, 2012. ISBN 978-92-79-21209-3. Available on Internet: http://ec.europa.eu/taxation_customs/resources/documents/taxation/ gen_info/economic_analysis/tax_structures/2012/report.pdf

[4] STOFKOVA, J. et al.: Finance and Financial Management (in Slovak), EDIS - University of Zilina, 2012. ISBN 978-80-554-0169-0

[5] Statistical Yearbook of the Czech Republic 2012. Czech Statistical Office, [online] Available on Internet: http://www.czso.cz/ csu/2012edicniplan.nsf/engkapitola/0001-12-eng_r_2012-1200

[6] Genesis - Online Datenbank. Destatis Statistisches Bundesamt. [online] [cit. 2013-02-02]. Available on Internet: https://www-genesis.destatis.de/genesis/online;jsessionid=CD98F78766583267A12D742C09F61CA0.tomcat_ GO_1_1?operation=previous\&levelindex $=3 \&$ levelid $=1365452777436 \&$ step $=3$

[7] Monitoring Revenue Trends and Tax Reforms in Member States 2008, 2009. 